\title{
The Amnesty Case of Baiq Nuril: A Study of Information Technology and the Virtue of News Media within Society
}

\author{
Rizka Fardy ${ }^{1}$, Hendra Kaprisma ${ }^{2}$ \\ \{rizka.fardy@ui.ac.id ${ }^{1}$, kaprisma@ui.ac.id ${ }^{2}$ \} \\ ${ }^{1}$ Faculty of Law Universitas Indonesia, Indonesia \\ ${ }^{2}$ Faculty of Humanities Universitas Indonesia, Indonesia
}

\begin{abstract}
The Fourth Industrial Revolution offers immense advantages and alsoseveral many-disadvantages. Industry 4.0 extends the human capability to perform good and bad acts with the emerging technologies that it possesses. In line with that, Industry 4.0 also acquires the potential of increasing inequality within society. Concerning Industry 4.0, the important thing that we should give attention to is the regulation in the field of Law of Information Technology. One of the issues as the impact of Industry 4.0 is the case of Baiq Nuril Maknun regarding sexual harassment by a phone call which sparks dialogue and critiques from various experts. Baiq Nuril Maknun was sentenced by the Supreme Court to 6 (six) months imprisonment and a fine of IDR 500,000,000 (five hundred million Rupiah) subsidiary 3 (three) months imprisonment. the Supreme Court judges considered that Baiq Nuril has violated Article 27 paragraph (1) of the Law No. 19 the Year 2016 regarding the amendment of Law No. 11 the Year 2008 regarding Information and Electronic Transaction (ITE Law). The case experienced by Baiq Nuril is a form of discrimination against women by law. The Supreme Court verdict on Nuril ignores a sense of justice towards women as victims. At the District Court level, Nuril was declared free, but when the prosecutor appeals this case to the Supreme Court, the verdict against Nuril was burdensome. The decision was deemed to deny the sense of justice because - in this case-Nuril'sposition as a victim of sexual violence was not considered by the Supreme Court judges to evaluate the decision. Thus, the decision made implications for the urge to grant amnesty from the President to Baiq Nuril. The case became a booming populist issue on news media. Through the study of Feminist Jurisprudence and the study of media within society. The Supreme Court's verdict on Baiq Nuril Makun's case will be examined in depth by taking into account the aspects of women's protection in the field of law. This paper aims to analyze the amnesty given to Baiq Nuril Maknun under Feminist Jurisprudence theory and media analysis within society
\end{abstract}

Keywords: feminist jurisprudence, gender, information technology, law, media.

\section{Introduction}

The National Commission on Violence Against Women (Komnas Perempuan) launched the Violence Against Women Note in 2018 (CATAHU 2019). In 2019, Komnas Perempuan recorded 406,178 cases of violence against women that were reported and handled during 2018. This shows an increase from the previous year, which recorded 348,466 cases. Cases of 
violence against women consisted of 13,568 cases handled by 209 service provider partner institutions spread across 34 Provinces, and 392,610 cases were sourced from case data or cases handled by the Religious Courts. The data show patterns and trends of violence against women in three domains, namely private, public, and state.

On the other hand, complaints of cases of violence against women in 2018 increased 14 percent from the previous year. This increase in complaints indicates a higher level of public awareness to reveal cases of violence against women and an improvement in the mechanism for recording and documenting cases of violence against women in service institutions (komnasperempuan.go.id). One of the cases that became public attention is the case of Baiq Nuril Maknun (better known as Baiq Nuril).

The Supreme Court (MA) has issued its Decision Number 574 K/Pid.Sus/2018 ("Supreme Court Decision") which sentenced herwith6 months in prison and a fine of Rp500,000,000 (five hundred million Rupiah) provided that if the fine is not paid, then it will be replaced with a sentence of imprisonment for 3 (three) months. Based on the Supreme Court Decision, Baiq Nuril is considered to have violated Article 27 paragraph 1 of the ITE Law. On January 3, 2018, Baiq Nuril submitted a decision review (Peninjauan Kembali/PK) to the Supreme Court. The Supreme Court through its Decision Number 83 PK/PID.SUS/2019 had rejected PK submission from Nuril. Due to public pressure, the execution of Nuril, which was supposed to be carried out on November 21, 2018, is postponed until President Joko Widodo granted amnesty for Nuril on July 27, 2019.

The case experienced by Baiq Nuril is a form of discrimination against women in front of the law. The verdict on Nuril ignores a sense of justice towards women as victims. At the District Court level, Nuril has been declared free, but when the public prosecutor appealed to the Supreme Court, the verdict against Nuril is burdensome.The Supreme Court verdict is considered to deny a sense of justice because-in this case-Nuril's position as a woman victim of sexual violence was not disclosed in court and was not considered by the judges to evaluate the decision. Therefore, Indonesia law is still considered less (not) in favor of women. This is what the author will examine through the Feminist Jurisprudence theory with normativeempirical methods and critical legal readings. Those are the important things that will be presented in this paper.

Based on the above introduction, the scope of the research in this article is regarding the criminal case of Baiq Nuril from the perspective of Feminist Jurisprudence and the power of media. In 2015, Baiq Nuril has been reported to the police with charges of violation of Article 27 paragraph (1) ITE Law by Muslims who is the principal of SMAN 7 in Mataram City, Nusa Tenggara Barat. The length of the legal process for Baiq Nuril until she has granted amnesty from the President of the Republic of Indonesia, Jokowi in 2019, will be the scope of this article as well. The relationship of Feminist Jurisprudence and the power of the media, especially media coverage in Indonesian society which finally had the effect of pushing President Jokowi as head of state and head of Indonesian government who has the authority to grant amnesty to Baiq Nuril after her Peninjauan Kembali (PK) was rejected by the decision of the Supreme Court on 26 September 2018.

Based on the background and scope of research that previously described, the formulation of the problem that will be examined in this paper is about how the guilty verdict issued by the Supreme Court for Baiq Nuril case is reviewed from the Feminist Jurisprudence theory which then raises the hypothesis of a gender bias in handling legal cases against women before the law. One of them happened to Baiq Nuril who was accused of violating the ITE Law, namely she was accused of distributing electronic information that contained content of decency. Baiq Nuril is a victim of verbal sexual harassment committed by Muslim as the Principal of SMAN 
7 Mataram City, but this issue or problem was not raised in the legal justice process which instead she was found guilty of. The problem is important to be raised because until now Indonesia's law is felt to be inseparable from the gender bias.

The purpose of this research is to identify the guilty verdict by the Supreme Court to Baiq Nuril through a review of the Feminist Jurisprudence and the role of the media, especially news media. Related with the strength of the role of the media, especially the news media, then this research also identifying the legal process in the case of Baiq Nuril from 2015-2019 in Indonesia and its impact on the views and support from the public shown to Baiq Nuril. This case that also affects the President of Indonesia who has authority to grant amnesty to Baiq Nuril included in the purpose of this research regarding the decision of the Supreme Court which found Baiq Nuril guilty of violations of the ITE Law, but was not legally processed about her who was also a victim of verbal sexual harassment cases.

The concept of Feminist Jurisprudence(Barnett, 1998) has been known since the 1980s. Since jurisprudence is a fundamental analysis of the legal relationship, concepts, and principles, feminist legal theories identify themselves as jurisprudence. Jurisprudence is considered-should-be a neutral analysis of universal legal principles so that the feminist school is interesting in itself-which produces its legal science-which is contradictory in terms. Feminists respond that Feminist Jurisprudence is nothing more than self-interest rather than a universal jurisprudence, which in reality is patriarchy as objective analysis of neutral legal principles. The law is often regarded as the legitimacy of men's perspectives. Thus, Feminist Legal Jurisprudence aims to eliminate bias against women in law.

In a broad sense, Feminist Jurisprudence is related to one or more of political theories. Liberal feminists-since Mary Wollstonecraft-have argued that liberal values must be applied equally to women. Marxist feminists argue that Marxist class analysis must be applied equally to gender. Socialist feminists assume that socialist principles must be used in eliminating coercion of sex. Feminist theory always points to the omission of a woman or what is now called gender discrimination in general political theory to which they are related. Feminist Jurisprudence can be combined with several other political views, from pragmatic, postmodern, or purely radical, or not related to certain theories. There is no Feminist Jurisprudence, there is no particular political view regarding the feminist school, except the feminist school itself, which is also a political view. So, all feminist theories are political.

On a superficial understanding, from a historical point of view, three main theories see that traditional legal science is not always divided. First, the Natural Law, which generally stipulates law as a rule of reasons disseminated for the common good by those who have authority. Second, Positive Law, which became dominant in the 19th century, established the law as a system of rules made by procedures that had authority. Third, the Legal Realism that developed in the 20th century, argues that the law is fundamental and can be avoided from politics. Thus, it can be said that for a long time legal science has been divided into two subcategories, namely normative law and descriptive law. The division was explained by John Austin, the 19th-century positivist, who dedicated his famous teaching "setting the province of jurisprudence as the proper designation". Positivists can assume natural law is wrong, but not that it is not natural law, nor can feminists be criticized. Feminist Jurisprudence is jurisprudence because it is a fundamental analysis of legal relationships, concepts, and principles. Blindness to the principle of "justice for all" makes feminist analysis one of the best as a lens of correction today.

The media in this context, according to Bourdieu, have the power to influence fields such as science, politics, or literature, because in the media there are "heteronomous individuals" who are people from outside but have little authority given values in the field. these fields 
(1996). One of the media contexts examined in this paper is the news media that are present in the community to explore an issue or problem in the social reality of people's lives at a particular time and place. The choice of one of the media fields is the news media because based on the understanding of the function of the news media is the news present as relevant media to provide "information that must be possessed by all citizens to exercise their democratic rights".

Media is one of the products of popular culture produced by a party which then becomes a commercial product that is consumed by the wider community. Because the media, one of which is the news media, is a product of popular culture, in this case, news also has a large and a strong role in reporting a thing or issue. The role and great strength of the media in the formation of opinions or views and perceptions in society. To be able to provide facts that happened, then the news media should preach a thing or event through the concept of cover both sides. In connection with the theme of this paper which examines the Baiq Nuril case, then the news media in this paper will examine how much intensity is given by the Indonesian news media in publicizing the coverage of the Baiq Nuril case which began in the judicial process in 2015 to be able to provide encouragement or influence to Indonesian people to this case, especially to Baiq Nuril who was able to get an amnesty from the President of Indonesia, Jokowi in 2019.

\section{Methods}

The method used in this paper is a qualitative method to find the connection between the feminist jurisprudence point of view with the role of the media, especially the online news media that gives influence and affect the progress Baiq Nuril case which in this matter could force the president of Indonesia granting amnesty for her. Besides, to discuss research methods that explore the legal cases inflicted on Baiq Nuril, normative-empirical research methods with critical readings are also used (Hanson, 1999). The normative-empirical legal research method is used to discuss the implementation of normative legal provisions (Laws) in any particular legal event that occurs in a community (Tyler, 2017), namely the Baiq Nuril case which received a guilty verdict from the Supreme Court, but afterwards was successful get justice from the President in the form of granting amnesty.

\section{Result and discussion}

The Supreme Court ruling regarding the Bike Nuril Maknun case, a former honorary teacher at SMAN 7 Mataram, who was sentenced to 6 (six) months in prison and fined Rp500,000,000(five hundred million Rupiah) was considered inappropriate. The Supreme Court convicted Nuril of violating the rules of the ITE Law by distributing electronic information containing moral content. Nuril is a victim of verbal sexual harassment by the Principal of the Mataram 7 Public High School when the headmaster harassed her through a telephone call. Nuril decided to record their conversation as evidence of sexual harassment. Although claiming to be uncomfortable with the behavior of her superiors, Nuril did not dare to complain about fear of being fired from his position as treasurer staff.

The existence of the recording was known to Imam Mudawin, Nuril's friend. Imam Mudawin distributed the recording to the Mataram City Education Office and others. The Principal was transferred from his position as the principal because of this incident. Not accepting that his recording is spreading, the Principal then reported Nuril insteadofImam, to 
the police based on the violation of Article 27 paragraph (1) of the ITE Law. Even though from the beginning Nuril did not distribute the recording, the criminal proceeding was continued until the Mataram City District Court decided Nuril was innocent and released him from the status of a city prisoner. Nuril is considered not fulfilling the element of "distributing and or transmitting and or making accessible information" containing decency. However, the Public Prosecutor submitted an appeal to the Supreme Court. The Decision of the Supreme Court Number $574 \mathrm{~K} / \mathrm{Pid}$.Sus/2018 is described as follows.

\section{MENGADILI}

- Mengabulkan permohonan kasasi dari Pemohon Kasasi/Penuntut Umum pada KEJAKSAAN NEGERI MATARAM tersebut;

- Membatalkan Putusan Pengadilan Negeri Mataram Nomor 265/Pid.Sus/ 2017/PN.Mtr tanggal 26 Juli 2017 tersebut.

\section{MENGADILI SENDIRI}

1. Menyatakan Terdakwa BAIQ NURIL MAKNUN tersebut di atas terbukti secara sah dan meyakinkan bersalah melakukan tindak pidana "Tanpa hak mendistribusikan dan/atau mentransmisikan dan/atau membuat dapat diaksesnya informasi elektronik dan/atau dokumen elektronik yang memiliki muatan yang melanggar kesusilaan";

2. Menjatuhkan pidana kepada Terdakwa oleh karena itu dengan pidana penjara selama 6 (enam) bulan dan pidana denda sejumlah Rp500.000.000,00 (lima ratus juta rupiah) dengan ketentuan apabila pidana denda tersebut tidak dibayar maka diganti dengan pidana kurungan selama 3 (tiga) bulan;

3. Menetapkan masa penahanan yang telah dijalani oleh Terdakwa dikurangkan seluruhnya dari pidana yang dijatuhkan;

4. Menetapkan barang bukti berupa:

- 1 (satu) buah CD yang berisikan isi rekaman pembicaran antara Haji Muslim dengan Baiq Nuril Maknun, dikembalikan kepada Haji Muslim;

- 1 (satu) buah Laptop Toshiba warna coklat ukuran 10 inch Nomor Seri 5C115626K dan 1 (satu) buah kabel data warna hitam, dikembalikan kepada Haji Imam Mudawin;

- 1 (satu) buah HP merek Samsung Champ Model GT-C3312, IMEI 356785/05006493/6, IMEI 356786/05006493/4 type dua kartu sim, dikembalikan kepada Muhajidin, S.Pd.;

- 1 (satu) buah memori card/external micro 2 GB, dikembalikan kepada Haji Hanafi, S.Sos.;

- 1 (satu) buah memori card merek V-Gen 2 GB, dikembalikan kepada Dra. Hj. Indah Deporwati, M.Pd.;

- 1 (satu) buah HP merek Nokia warna hitam silver Type RM-578, Code 059COR4, IMEI 354870/04/771208/6 dalam keadaan rusak, dikembalikan kepada Terdakwa;

5. Membebankan kepada Terdakwa tersebut untuk membayar biaya perkara dalam tingkat kasasi sebesar Rp2.500,00 (dua ribu lima ratus rupiah);

Demikianlah diputuskan dalam rapat musyawarah Majelis Hakim pada hari Rabu tanggal 26 September 2018, oleh SRI MURWAHYUNI, S.H., M.H., Hakim Agung yang ditetapkan oleh Ketua Mahkamah Agung sebagai Ketua Majelis, MARUAP 
DOHMATIGA PASARIBU, S.H., M.Hum., dan Dr. H. EDDY ARMY, S.H. M.H., Hakim-Hakim Agung pada Mahkamah Agung sebagai Hakim-Hakim Anggota, putusan tersebut diucapkan dalam sidang terbuka untuk umum pada hari dan tanggal itu juga oleh Ketua Majelis beserta Hakim-Hakim Anggota serta SRI INDAH RAHMAWATI, S.H., Panitera Pengganti dengan tidak dihadiri oleh Penuntut Umum dan terdakwa.

The Supreme Court verdict for the Baiq Nuril Maknun case above shows that law enforcement in Indonesia is very alarming. The issue of law enforcement has always been a complicated problem for many parties, especially because of the imbalance of interactions between legal aspects in expectations (das sollen), and aspects of the application of the law in reality (das sein). This is compounded by another imbalance, namely gender. The problem is compounded by the complicated ITE Law. The ITE Law should cover women's protection and considered women as victims' points of view. Articles in the ITE Law are often used as tools and even are misinterpreted or misused. Baiq Nuril is not the only victim of the implementation of ITE Law. Therefore, there needs to be a distinction between cases of sexual abuse experienced by Baiq Nuril and other information and technology violation cases.

The Nuril's action to record the phone call conversations to protect herself from acts of sexual harassment from her superior and to collect pieces of evidence so people will trust her. This evidence was presented by the Prosecutor as proof that Nuril was intentionally recorded the conversation and spread it to the other people, which then led to Nuril being sentenced. The prosecutor and Supreme Court judges have ignored the fact that Nuril's actions are part of her self-defense effort so as not to become a victim.

The Criminal Procedure Code must divide this case into two different (though interrelated) cases. The first case is that a mother of a toddler, as well as an honorary teacher, is contacted several times by a school principal and often talks about inappropriate matters that should not be. Given the fact that the relation between Nuril and the Principal is the only relation between superiors and subordinates, plus the inconvenience of Nuril being treated as such, it is logical to understand that sexual harassment through phone call conversation has happened to Nuril. In law, sexual harassment can be constructed by its criminal element, although it needs to be done carefully. Criminal pornography in Indonesian criminal law (both the Criminal Code and Lexspecialis) generally emphasizes the existence of a "public" element. For someone who produces pornographic content, this action can be qualified as a criminal offense if the thing produced-for example-is publicly disseminated.

Article 294 of the Criminal Code can be a basis for Nuril to report the Principalactions. Paragraph 2 (1) of this article regulates, "Threatened with the same crime: officials who commit obscene acts with a person whose position is subordinate, or with a person whose safeguards are entrusted or handed over to him". The threat of punishment is seven years in prison. So, the first case is a case of alleged sexual harassment (by verbal) by the Principal. The second case is about the distribution of pornographic content which then ensnares Nuril with Article 27 paragraph 1 of ITE Law. There are three criminal elements in this article, namely distributing and/or transmitting and/or making accessible Electronic Information and/or Electronic Documents that have content that violates decency. The Supreme Court judges consideration stated that Nuril was legally and convincingly proven to transmit the recorded sound with the Principal. Even though in the first instance of the trial, the person who transferred the recording was not Nuril but someone else. Regarding this second case, even though the verdict of the Mataram District Court was free (vrijspraak) for Nuril, it turned 
out to be appealed instead. The Attorney General's Office stated that the decision of the Mataram District Court for Nuril was to be impure (lepas-oonslaag)

Therefore, the law should be close to the people themselves in a particular value system. The development of the current legal system discussion has developed dynamically from a rigid pattern (rigid-positivist-radical to what is written) to an open pattern that emphasizes the balance of what is set in writing with what most people feel is justice. This stance is not saying that the law means submitting to the majority vote, but rather emphasizing that justice itself is the same universal value that exists in every human being. That could explain why many demonstrations took place broadly in the case of the verdict experienced by Baiq Nuril. Public disappointment coupled with the fact that the law enforcement system is still full of corruption and the pattern of law formation of the legislature is still too much political compromise. It is right to say that a legal system is bad because the people in it are also bad. This fetter that allows the process of law enforcement and judicial decisions feels far from the sense of justice itself.

The Supreme Court judges also have ignored legal protection against women in Indonesiareflected in supreme Court RegulationAgung (Perma) Number 3 of 2017 concerning Judicial Guidelines for Women's Cases Dealing especially in Chapter III Article 4 Article 5 letter c, Article 7regarding the examination of the case. Such Permai's guidance for Supreme Court judges in carrying his duty is to examine women cases before the law. The judges must consider gender equality and consider things that have a relation with discrimination within handling women's cases before the law. In particular, in Article 7 there is a statement which states that during the case examination in the Supreme Court as much as possible the judges have to prevent not using experience the background of moderate female sexuality dealing with law in Indonesia. This condition shows that if the Supreme Court judge examines a case that involves the victim or the suspect is a woman then the judges should use this Perma as guidance to handle women cases in the Supreme Court.

\subsection{The Amnesty Grant and the Virtue of the Media}

The event of Amnesty given to Baiq Nuril related to the rejection of the Supreme Court's decision on the Judicial Review (PK) of Baiq Nuril's legal issues was given by President Jokowi on July 31, 2019. The Amnesty event was not granted suddenly by the President of the Republic of Indonesia but was given after a long time and the complexity of the legal case faced by Baiq Nuril for approximately 4 years. During those 4 years, the Baiq Nuril case was known to not escape the attention of the President of Indonesia and the people of Indonesia. Various concerns, responses, and support shown for Baiq Nuril also involve the role played by the media, especially the news media in guarding this case to the public. 


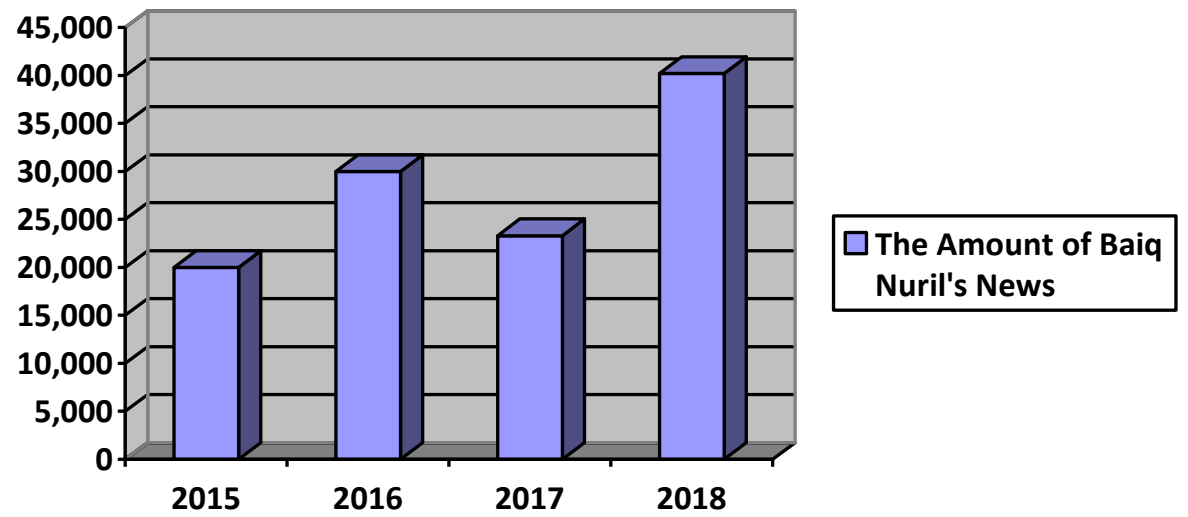

Fig.1. News media in guarding the case

Based on data recorded from keyword search results on Google Search, the news of the Baiq Nuril case from 2015 to 2019, the large number of news that appeared on Google Search shows that there is a tendency for Baiq Nuril to report an increase in the quantity of news from year to year. In 2015, from the date, the number of news obtained based on the keyword "Baiq Nuril 2015" obtained a total of news that appeared on Google Search by approximately 20,000 results. Furthermore, in 2016 with the keyword "Baiq Nuril 2016" in the news search on Google Search, it found as many as approximately 30,000results, in 2017 decreased by only about 23,300 results with the search keyword on Google Search namely "Baiq Nuril 2017". Then in 2018 there was an increase in the number of news that was recorded in Google Search with the search keyword "Baiq Nuril 2018" of approximately 40,200 results and in 2019 it had a peak increase of approximately 66,200 results with the keyword "Baiq Nuril 2019" in search news published by the news media on Google Search.

The themes raised by the news media about Baiq Nuril's case change every year because they follow the dynamics of the Baiq Nuril case development. Like in 2015 where most of the news themes raised the beginning of the story about the Baiq Nuril case which began in 2012 . Then in 2016 raised the news theme of the Baiq Nuril case about the ITE Law and the sentence of imprisonment for Baiq Nuril, in 2017 raised the theme of the request for justice for Baiq Nuril to the President, in 2018 about the perpetrators of verbal sexual harassment namely Muslim to Baiq Nuril, and its peak in 2019 which ended the Baiq Nuril case with the issuance of Presidential Decree (Keputusan Presiden) Number 24 of 2019 concerning amnesty for Baiq Nuril.

The ongoing reporting on the Baiq Nuril case has led to various support from the community such as one of the guarantor of the arrest of defendant Baiq Nuril in 2019, namely the Head of Social Service, Head of Trade Office, Head of Women Empowerment and Child Protection Office, Chairperson of the East Lombok DPRD, and Chairperson of Commission V of the NTB Provincial DPRD. Besides, the representatives of the community at an institution called the Coordinator of the Commission for Missing Persons and Victims of Violence (Kontras) also helped to investigate the problem of legal injustice regarding the Baiq Nuril's case. Reinforcements from various parties to the community were formed from the consistency of the news media, especially the news media in Indonesia in exposing the facts peppered with emotional stories from the Baiq Nuril case so that this also did not escape the 
attention of the President of the Republic of Indonesia, Joko Widodo. The President's attention was also supported by a wave of people who refused Baiq Nuril to be detained as suspects through an online petition on the change.org page made by the Civil Society Coalition with the "Save Mother Nuril" hashtag in that petition.

The final struggle of the Baiq Nuril's case given to him an amnesty by the President of Indonesia in 2019 has suggested that in the Indonesian state, there has been concrete evidence of guarantees that women get protection before the law. Amnesty itself is a remission or abolition of the punishment given by the head of state to a person or group of people who commit a certain crime. Article 4 of Law No. 11 of 1954 concerning Amnesty said the consequences of granting amnesty were all the consequences of criminal law against those who were granted amnesty abolished. By granting amnesty to Nuril, it can be guaranteed that women will get protection in law.

\section{Conclusion}

The construction of society to date shows that almost in every sphere of life cannot be separated from men (patriarchy). Women are considered as the other "the Other" in the construction of the patriarchy (Beauvoir, 1997). Women are considered inferior compared to men. This assumption causes women to not make a voice in the public sphere. Through a review of Feminist Jurisprudence, women's inferiority was seen in the legal case experienced by Baiq Nuril.

The judge's sentence to Nuril was considered inappropriate because Nuril's position as a victim of sexual violence was not revealed in court and was not used by the judge to evaluate the decision. Judges often ignore MA Regulation (Perma) Number 3 of 2017 concerning "Guidelines in Judging Women Who Are Confronting the Law". It can be a "light" of hope for women affected by legal cases.

However, the existence of an amnesty given by Indonesian President Joko Widodo has given hope again that the head of state, as well as the head of the Indonesian government who holds the highest authority in the realm of law, is finally willing to grant amnesty to the Baiq Nuril case. The event of granting amnesty to Baiq Nuril is inseparable from the role of the media, especially the news media, which continuously and consistently from 2015-2019 reported the development and dynamics of the Baiq Nuril case so that there was encouragement from the public for the President of Indonesia to grant amnesty to Baiq Nuril. Also, the role of the media has succeeded in helping the President to continue to be able to monitor and make amnesty decisions.

\section{Author's Bio.}

Rizka Fardy; is currently enrolled as a graduate student pursuing a Masters in Economic Law at Faculty of Law, Universitas Indonesia (UI). She earned her bachelor's degree from the Faculty of Law UI back in 2007. She is an advocate and senior Associate of Harvard, Marieta Mauren Attorneys at Law firm specializing in litigation and employment cases. She started her career at Legal Clinical Aid and Alternative Dispute Resolution Faculty of Law Universitas Indonesia where she assisted various litigation cases from family law, criminal law, civil law, employment, and corporate law.

Hendra Kaprisma, is a lecturer of the Department of Literature, Faculty of Humanities, Universitas Indonesia (UI). Every day he supports lectures at a bachelor's degree in Russian Studies Program and a graduate degree in Literature Studies Program of Faculty of Humanities 
UI. He completed his undergraduate education in 2008 at the Russian Studies Program of Faculty of Humanities UI. Later on, he continued his doctoral studies in Literature Studies of Faculty of Humanities UI until he graduated in 2015. In 2011-2012 he attended Sandwich Ph.D. Program at Saint-Petersburg State University.

\section{References}

[1] Barnett, Hilaire. Introduction to Feminist Jurisprudence. London: Cavendish Publishing Limited. (1998).

[2] Beauvoir, Simone de. The Second Sex. Trans. Ed. H. M. Parsley. Vintage Book Edition. (1997).

[3] Bourdieu, Pierre. (1996). On Television. New York: The New Press.

[4] Douglas, Carol Anne. "Feminist Jurisprudence", Off Our Backs, Vol. 13, No. 5, Women \& The Law: 14th National Conference. (1983).

[5] Hanson, Sharon. Legal Method. London: Cavendish Publishing Limited. (1999).

[6] Komnas Perempuan. Siaran Pers Catatan Tahunan (CATAHU) Komnas Perempuan 2019. Accessed through komnasperempuan.go.id on 17 May 2019. (2019).

[7] Kontributor BBC. “Baiq Nuril Perekam Percakapan 'Tidak Senonoh' Kepala Sekolah di Mataram, Akan Ajukan PK”, BBC. Accessed through www.bbc.com on 17 May 2019. (2018).

[8] Kontributor BBC."Baiq Nuril, amnesty Pertama Untuk korban pelecehan seksual: 'Belum selesaikan masalah secara struktural'", BBC. Accessed through www.bbc.com on 5 September 2019. (2018)

[9] Kontributor CNN Indonesia."Kronologi Kasus Baiq Nuril, Bermula dari Percakapan Telepon”, CNN Indonesia. Accessed through www.cnnindonesia.com on 17 May 2019. (2018)

[11] Kontributor Kompas TV."Baiq Nuril: Pak Presiden, Saya Minta Keadilan, Saya Cuma Korban”, Kompas. Accessed through regional.kompas.com on 17 Mei 2019. (2018).

[12] Mahkamah Agung. 2018. Putusan Nomor 574 K/Pid.Sus/2018. Accessed through putusanmahkamahagung.go.id on 17 May 2019. (2018)

[13] Rajagukguk, Erman. Filsafat Hukum. Jakarta, Fakultas Hukum - Pascasarjana, Universitas Indonesia. (2017).

[14] Tyler, Tom R."Methodology in Legal Research”, Utrecht Law Review. Vol. 13, Issue 3. (2017). 